\title{
The effects of stakeholder integration on firm-level product innovativeness: Insights from small and medium-sized enterprises in Ghana
}

\author{
Samuel Adomako'; Joseph Amankwah-Amoah²; Albert Danso ${ }^{3}$
}

\author{
Corresponding author: J.Amankwah-Amoah@kent.ac.uk
}

Biographical endnote

Dr Samuel Adomako is a lecturer in strategy at the School of Management, University of Bradford. His research examines the nexus of entrepreneurship, innovation, and creativity and decision making process of small business internationalization. His research has appeared in leading journals including International Small Business Journal, Business Strategy and the Environment, Journal of Business Research, Journal of International Management and many others. He received his PhD from the University of Warwick, United Kingdom.

Dr Joseph Amankwah-Amoah is an Associate Professor (Reader) of international business at University of Kent. His research interests include strategic renewal, global business strategy, business failure, and lateral hiring in emerging economies. He has published in many journals of international repute including Technological Forecasting and Social Change, Industrial and Corporate Change, International Journal of Human Resource Management, Business History, Group and Organization Management, International Journal of Production Economics, and Journal of Business Research. He currently serves as an Associate Editor for Critical Perspectives on International Business and co-editor of the Cogent Business \& Management.

Dr Albert Danso is an Associate Professor in Accounting and Finance within the Leicester Castle Business School at the De Montfort University. Albert's teaching and research interests cut across Finance and entrepreneurship. His research has appeared in journals like International Review of Financial Analysis, Business Strategy and the Environment, International Small Business Journal, Managerial Finance, Journal of Business Research, Industrial Marketing Management, Journal of Small Business and Enterprise Development, Venture Capital, Journal of General Management and International Journal of Entrepreneurial Behaviour and Research. He received his $\mathrm{PhD}$ in Finance from the University of York, United Kingdom.

\footnotetext{
${ }^{1}$ School of Management, University of Bradford, Bradford, United Kingdom Email: S.Adomako@ bradford.ac.uk

${ }^{2}$ Kent Business School, University of Kent, UK. Email: J.Amankwah-Amoah@kent.ac.uk

${ }^{3}$ Leicester Business School, De Montfort University, Leicester, UK. Email: Albert.danso@dmu.ac.uk
} 


\begin{abstract}
In spite of growing research on the influence of external stakeholders on firm outcomes, there is a paucity of research on how they influence innovation in emerging economies. In addition, the specific environmental factors that may influence the effect of stakeholder integration (SI) on firm innovation is less understood. Using data collected from 248 small and medium-sized enterprises (SMEs) in Ghana, this paper develops and tests a model that examines the relationship between SI and firm-level product innovativeness. The findings from the study indicate SI positively relates to product innovativeness. Moreover, under conditions of higher competitor pressure and greater customer expectations, the effect of SI on product innovativeness is amplified. Contributions for theory and practice are discussed.
\end{abstract}

Key words: Product innovation; stakeholder integration; market environment; emerging economy; Ghana 


\section{Introduction}

Today's rapidly changing global environment has led to increasing competition and opportunities in emerging markets (Cavusgil, Ghauri and Akcal, 2012; Cavusgil, Knight and Riesenberger, 2012), thereby prompting both developed and emerging-market firms to increase their innovation activities. There is a conventional wisdom that ground-breaking innovations predominantly come from advanced Western countries, and that advanced-economy firms perform better than their emerging-market counterparts (Luo, Sun and Wang, 2011). A major explanation is that the well-developed institutional structure found in advanced economies support innovation activities (Luo and Tung, 2007; Story, Boso and Cadogan, 2015). For emerging-market firms, it has been suggested that to be able to understand and respond faster to changes in the rapidly changing environment, stakeholder integration is important (Alsos, Hytti and Ljunggren, 2011). Thus, the innovation process of firms can be enhanced by

reinventing the way firms relate and integrate different stakeholders into their decision making and practices. Indeed, in the absence of business-supporting institutions and technological competencies, emerging-market firms can integrate stakeholders such as communities, customers and suppliers into their decision-making process as a means of gaining, maintaining or repairing organisational legitimacy (Desai, 2018; Jonas et al., 2018; Watson et al., 2018). By collaboratively engaging with dispersed stakeholder groups, firms can access previously unavailable information (Desai, 2018) and improve their overall performance (Goodman et al., 2017).

Broadly speaking, stakeholder integration (SI) reflects partnerships developed by firms with stakeholders such as customers, communities and suppliers to inform organisational practices to deliver improved performance (Desai, 2018; Sharma and Vredenburg, 1998). Accordingly, SI has been conceptualised as a three-dimensional construct entailing firms' knowledge of stakeholders, interaction with stakeholders and adaptation to stakeholder demands (Plaza-Úbeda et al., 2010). By utilising knowledge gained from external stakeholders, firms can develop their innovation capability (Ayuso et 
al., 2006; Galunic and Rodan, 1998). Indeed, past studies indicate that firms that integrate stakeholders such as customers tend to receive favourable reviews (Dahl et al., 2014). By incorporating stakeholders, firms can stay in tune with customers' requirements and accordingly are better able to comprehend and respond faster to changes in the rapidly changing environment (Alsos et al., 2011). This improves their competitiveness and enables them to gain competitive advantage. Accordingly, SI appears to be essential for firms in an era of global competition.

Notwithstanding the importance of SI in firm outcomes (Desai, 2018; Jonas and Roth, 2017; Jonas et al., 2018), our understanding of how SI influences firm innovativeness in emerging economies is limited. In addition, the specific environmental conditions under which SI effectively drives innovation are not well understood.

In this study, we attempt to fill these knowledge voids by examining the link between SI and firm-level innovativeness in an emerging market and how this relationship is moderated by competitive intensity and customer demandingness. The issue of customers' expectation and competition in emerging markets compared with advanced economies offers some interesting insights. Most emergingmarket customers tend to patronise goods that come from advanced economies. As such, local companies tend to face fierce competition from imports from advanced Western economies. In developed countries, however, consumers are more likely to patronise products or services based primarily on price, quality and durability. These issues are particularly important given that much of the current literature on the concept of engagement tends to focus on customer engagement with firms or brands (Jonas et al., 2018) with limited attention paid to SI by small firms in emerging markets.

We extend stakeholder theory and innovation literature in two specific ways. First, although some studies have suggested stakeholder engagement as a basis for innovation (e.g. Ayuso et al., 2006, 2011; Jonas et al., 2018), there remains a paucity of scholarly works on emerging economies. We shed light on the effects of a firm's knowledge of stakeholders, interaction with stakeholders and 
responsiveness to stakeholder requirements on the degree to which it innovates. Second, we deepen our understanding of SI (Driessen et al., 2013; Jonas and Roth, 2017; Jonas et al., 2018; Watson et al., 2018) by demonstrating how stakeholder initiatives can influence a firm's performance and ability to innovate. Specifically, we introduce competitor pressure and greater customer expectations as conditions that boost a firm's SI capability to innovate. Thus, we highlight the conditions under which SI is more effective in enhancing firm innovation.

After presenting a review of the literature on stakeholder and firm product innovativeness, we set out the approaches to data collection and data analysis. We then outline the significant findings, followed by the implications for theory and practice.

\section{Theoretical background and hypotheses}

\subsection{Stakeholder theory}

Stakeholder theory is often used as a theoretical perspective to explain how firms manage their relationships with actors in complex environmental settings (Freeman, 1984; Goodman et al., 2017). The theory advocates for firms to maintain "simultaneous attention to the legitimate interests of all appropriate stakeholders" (Donaldson and Preston, 1995, p. 67). Anchored in stakeholder theory is the suggestion that different stakeholders can exert pressure on firms to alter their behaviour by adopting new work practices and routines (Eesley and Lenox, 2006; see also Jamali and Karam, 2018). In the remit of this theory, "SI" is considered a crucial firm capability that can help firms establish social legitimacy. By encouraging and fostering stakeholder participation in product or service development, firms are able to achieve improved innovation outcome (Vargo and Lusch, 2004) and firm performance (Ommen et al., 2016; Phillips et al., 2017).

One of the ways in which stakeholders contribute to organisational efforts is by offering new ideas and suggestions which ultimately help the organisation improve product design and processes and eliminate inefficient practices (Ommen et al., 2016). Stemming from these studies is the suggestion 
that the extent to which stakeholders are integrated into the management of a firm can be a source of capability that may help the firm obtain a competitive advantage. Therefore, the SI concept has been put forward to refer to the extent to which stakeholders' voices are inculcated into the decision-making process, and this notion has been conjectured to be crucial for a firm's product innovativeness (Hart, 1995). Thus, SI entails three key variables, i.e. knowledge, interaction and behaviours of adaptation (Cadogan et al., 2006).

\subsection{Firm-level product innovativeness}

The innovation literature suggests five main areas that describe a firm's overall innovation agenda: behavioural innovation, product innovation, process innovation, strategic innovation and market innovation (e.g. Tajeddini et al., 2006; Wang and Ahmed, 2004). Broadly speaking, firm innovativeness represents a firm's overall capability to introduce new products and services into the market or set up new markets via the introduction of strategies oriented towards the firm's overall innovation mission (Wang and Ahmed, 2004). The literature indicates that well-performing firms are innovative because they tend to respond continuously to environmental changes (Peters and Waterman, 1982). Innovative firms tend to be open to novel ideas as a way to exhibit their corporate culture (Hurley and Hult, 1998)

In this study, we focus on product innovativeness to understand how SI drives this important dimension of firm innovativeness. Product innovativeness is conceptualised here as "the propensity for a firm to innovate or develop new products" (Garcia and Calantone, 2002, p. 113). This indicates that product innovativeness is a firm's perception of how new, novel, original or unique a product is (Henard and Szymanski, 2001). In this study, product innovativeness refers to a firm's ability to introduce new and unique products into the market in a timely manner. This study focuses on product innovativeness for two main reasons. First, a firm's spending decisions on how to generate and develop innovative capabilities mostly take place within the organisation (Story et al., 2015). For example, a number of firms assess return on investment of their R\&D capabilities at the firm level (Özçelik and Taymaz, 
2004). Second, a firm's ability to innovate tends to portray how competitive the firm is; hence, a focus on firm-level product innovativeness offers a crucial research agenda (Özçelik and Taymaz, 2004; Story et al., 2015).

\subsection{Innovation in emerging and developed markets}

The potential benefits to sub-Saharan and other emerging countries from innovation are enormous (Obeng, Robson and Haugh 2012, Robson, Haugh and Obeng 2009). In emerging markets, we know that innovation is focused on the incremental changes to practices rather than radical new products (Robson et al. 2012). The ability of firms to bring innovative ideas to market and adopt new processes increases knowledge spillovers in a locality or region (Delmar, Karl Wennberg and Hellerstedt 2011). When firms exploit incremental innovation and adopt new practices this promotes local development (Romanelli and Khessina 2005). Developed economies are typified by features such as well-developed education systems, highly competitive industries attributed to historical embrace of deregulation and liberalisation, high per capita income and well-developed commercial infrastructure (Cavusgil et al., 2012; Cavusgil et al., 2012). These features coupled with limited government intervention in business have been found by past studies to buttress innovation activities not only for large firms but also small firms (see Afuah, 2009). Conversely, barriers to innovation or lack of enabling factors in emerging markets are likely to differ between those relating to radical innovation and the introduction of more incremental innovations.

Resource barriers in the areas with low levels of resource munificence may encourage firms to focus their managerial energies on better work practices, new office systems or amended business models (Robson et al., 2012). In addition, emerging economies often have uncompetitive or emerging industries and high levels of state intervention. As such, the competitive pressures to innovate by tapping into the insights and knowledge of customers and other stakeholders are minimal. Besides exhibiting opportunities such as rapidly growing economies, improving living standards and rapid 
industrialisation, emerging markets also face constraints such as weak intellectual property protection, widespread corruption, government red tape and feeble legal enforcement systems, which curtail small and medium-sized enterprises' (SMEs) ability to innovate, thrive and grow (Amankwah-Amoah et al., 2018; Cavusgil et al., 2012a, 2012b). This wider view of innovation is more appropriate within the context of emerging countries where the enabling factors for radical innovation are less likely to be found (Robson et al., 2012).

Figure 1 presents our conceptual model and the hypotheses. Innovativeness is influenced by stakeholder integration. That is, this study argues that stakeholder integration is positively related to firm innovativeness. In addition, this study argues that the level of market environment (competition and customer demandingness) boosts the effect of SI on innovativeness. The next section explains and develops hypotheses for each of these relationships.

\section{Insert Figure 1 about here}

\subsection{Stakeholder integration and firm-level product innovativeness}

One of the main objectives of this study is to explore the relationship between a firm's SI capability and its product innovativeness. It has been suggested that a firm's sustainable innovation development requires a wide range of SI (e.g. Phillips et al., 2017). This indicates that effective SI through managerial actions and initiatives is an organisational capability (Hart and Sharma, 2004). As such, it represents an opportunity to inculcate fresh ideas that could lead to a ground-breaking innovation process when a firm interacts with its stakeholders and integrates them into its decision-making process. Besides improving customers' experiences, harnessing customers' insights can equip organisations to create integrated and personalised offerings that fulfil customers' requirements (Chesbrough, 2006; Sawhney et al., 2006). 
Some researchers have contended that a firm's integration of stakeholders into its management brings innovation to the firm (e.g. Ayuso et al., 2011; Holmes and Smart, 2009). Similarly, the literature shows that firms that integrate multiple stakeholders into their new product development activities gain greater success (e.g. Talke and Hultink, 2010; Driessen and Hillebrand, 2013). This study argues that stakeholders, including consumers and governments, can also force firms to innovate or risk losing their competitiveness. Thus, increasingly, business success is predicated on a firm's ability to innovate whilst concurrently responding to environmental and social pressures exerted by different stakeholders (Ayuso et al., 2006; Senge and Carstedt, 2001). For instance, Ayuso et al. (2006) have emphasised the use of stakeholder dialogue as a source of new knowledge and ideas which can be

utilised by firms to innovate. The success of such an approach may be predicated on the superior skills and abilities of executives to interact with customers in a manner that produces productive conversations. By engaging in stakeholder dialogue for insights to innovate, firms are more likely to develop products that are in tune with customers' demands (Ayuso et al., 2006). Accordingly, this study proposes that:

H1: A firm's SI capability is positively related to firm-level product innovativeness.

\subsection{Moderating effect of market environment}

As shown in Hypothesis 1, the integration of stakeholders is considered a source of ideas for innovation. Through stakeholder integration, firms are able to understand and respond faster to changes in the rapidly changing environment (Alsos et al., 2011). Thus, the innovation process of firms can be enriched by integrating different stakeholders into the firm's decision-making and practices. However, the market environment conditions under which SI is more or less effective in driving innovation is still poorly understood. Therefore, research must account for how market environment conditions can drive the integration of stakeholders into firm innovation activities. Using insights from the classical contingency perspective (Lawrence and Lorsch 1967; Lumpkin and Dess 1996), this study investigates 
the moderating role of competition and demanding customers on the SI-firm product innovativeness linkage. The main tenet of the contingency theory is that firms' actions are affected by forces in the external environment. Prior research shows that the environment in which firms operate plays a fundamental role in determining firms' actions (Covin and Slevin 1991). Specifically, a firm's environment has been partitioned to include competitors, customers and technology (e.g. Germann, Lilien and Rangaswamy 2013; Jaworski and Kohli, 1993). This study focuses on competitive intensity and customer demandingness because research indicates that competition and customer issues are the main determinants of uncertainty (Germann, Lilien and Rangaswamy, 2013). Competitive intensity reflects a condition of strong rivalry between competitors operating in the same industry. In this situation, a firm's behaviour depends to a large extent on the way competitors behave, which creates a high degree of volatility and uncertainty leading to fewer opportunities in the market (Auh and Menguc, 2005). Customer demandingness is a market condition in which customers are characterised by higher expectations about products and services (Wang and Netemeyer, 2002). When managers perceive customers as demanding, it may offer them an opportunity to seek views from stakeholders in order to learn new strategies for further advancement and innovation.

Firms operating in emerging markets face some market competition. As such, the question relating to how best to engage with those environments has been a major focus of several studies (e.g. Adomako, Opoku and Frimpong, 2017; Ayyagari, Demirgüç-Kunt and Maksimovic, 2011; Cui, Griffith and Cavusgil, 2005). The main strategic decision revolves around the issue of how the integration of stakeholders into a firm's management process could generate innovation in high or low competitive environment conditions. In this study, we contend that when competition is intense, the relationship between SI and firm innovativeness should be more positive because firms need to innovate by reinventing the way they relate to their multiple stakeholders (e.g. employees, customers, suppliers, NGOs/activists, communities, governments, competitors, etc.). A major rationale is that 
firms need to actively manage relationships with stakeholders to gain ideas for innovations to satisfy customers, under highly competitive conditions (Jaworski and Kohli, 1993). For example, in a hypercompetitive and demanding customer marketplace firms in emerging markets cannot afford to ignore their primary responsibility towards product innovation. Conversely, under conditions of low competition intensity and low customer pressure, the integration of stakeholders may not yield superior innovation outcomes simply because there is no competitive pressure to justify additional investments in greater numbers of innovative new products.

Given that stakeholder integration is resource intensive which allows the firm to build strategic relevant relationships with their stakeholders (Ayuso et al., 2006; Grant, 1996), in environments without compelling competitive and customer pressures on firms to integrate relevant stakeholders, investing in stakeholder activities might not yield the required innovation outcomes. Accordingly, we contend that when competition intensifies, and when customers demand more innovative products, it may then become the case that the basis for sustaining superior competitive advantage may be predicated on a firm's level of integrating stakeholders' novel suggestions and ideas into the decisionmaking process, enabling the firm to generate greater positive innovative products to secure goodwill. Thus, we propose the following hypotheses:

$\mathbf{H}_{2 \mathbf{a}-\mathbf{b}}$ : The positive effect of a firm's SI capability on firm-level product innovativeness will become more positive when (a) competitive intensity is higher and (b) customer demandingness is greater.

\section{Research method}

\subsection{Research context}

Using Ghana as our empirical setting for an emerging economy, we examine this pivotal issue.

This study uses data from a sample of chief executive officers (CEOs)/managers in SMEs in the manufacturing sector in Ghana. Ghana is considered an important context in validating the research 
hypotheses for several reasons. First, Ghana operates an open-market economy which provides a rich context for examining how Western theories perform in a sub-Saharan economy such as Ghana (Banin et al., 2016). Second, Ghana's long-standing tradition of democracy provides a conducive environment for conducting business in West Africa (World Bank, 2011). Third, Ghana's economy has chalked up substantial growth over the last decade, thereby making the country one of the strongest-performing economies in sub-Saharan Africa (World Bank, 2017). The national government in recent years has sought to boost economic growth by diversifying the national economy to increase the contributions of manufacturing and service industries. Accordingly, the country recorded a GDP growth rate of $8.5 \%$ in 2017 largely due to political stability and new activities in the oil and gas, and agriculture subsectors (World Bank, 2017). Thus, examining SI and firm product innovation in Ghana provides a rich emerging-market perspective in understanding the role of stakeholders in bringing innovation to the firm.

\subsection{Sample and data sources}

The sampling frame of the study was developed from the Ghana Revenue Authority database. This database contained 17,254 manufacturing SMEs. Our sample consists of SMEs because they are a source of innovation for sustained firm growth in emerging economies such as ones in sub-Saharan Africa (Cimoli et al., 2009). In July 2016, we randomly contacted 1,100 firms via telephone to ask for their participation in the study. Subsequently, we selected 900 firms based on the following criteria: (1) independent entities that do not form part of any company group; (2) firms employing a minimum of five and a maximum of 250 full-time employees; (3) firms that manufacture physical products and engage in productive business activities; (4) firms with five years' business-operation experience; and (5) firms with complete contact details of the CEO/entrepreneur.

Subsequently, the CEOs/managers of the 900 SMEs were contacted in person with a questionnaire. An international research company with highly trained field researchers administered 
the questionnaire. The lead author of this paper supervised the research process and received 268 responses, representing a $29.77 \%$ response rate. The 632 firms that did not return their questionnaires cited reasons including company policy on disclosure and confidentiality.

To test for informant competency, each CEO/manager reported on a 7-point Likert scale ranging from $1=$ strongly disagree to $7=$ strongly agree to examine knowledgeability of the respondents on the subject matter, accuracy about the information they have given and confidence in providing answers to the questions (Morgan et al., 2004). In total, 248 complete responses were obtained, representing a $27.5 \%$ response rate. Results of the informant competency analysis show a mean of score of 5.32 $(\mathrm{SD}=.43)$ for issues on whether they are knowledgeable about the survey or not, $5.46(\mathrm{SD}=.52)$ for how accurate they are in responding to the questions, and $4.88(\mathrm{SD}=.39)$ for their confidence level in responding to the questions. This study therefore relied on 248 useable responses for the analyses. This study followed Armstong and Overton's (1977) to establish whether non-response bias affects the analyses by dividing the data into early and late respondents. The results show no substantial discrepancies between the two groups. Hence, it is concluded that the analyses were not affected by non-response bias.

\subsection{Measures}

All the measures were taken from previous research. The multi-items were measured on a 7-point Likert scale ranging from $1=$ strongly disagree to $7=$ strongly agree

\subsubsection{Stakeholder integration}

Using the scale of Plaza-Úbeda et al. (2010), this study conceptualises SI as a three-dimensional construct, entailing firms' knowledge of stakeholders, interaction with stakeholders and adaptation to stakeholder demands. A firm's knowledge of stakeholders was measured with four items. Similarly, four items captured a firm's level of stakeholder interaction. Finally, five items measured a firm's 
adaptation to stakeholder demands. The reliability of knowledge of stakeholders $(\alpha=.88)$, stakeholder interaction $(\alpha=.85)$ and adaptational behaviour $(\alpha=.97)$ was acceptable. The SI scale $(\alpha=.90)$ is the mean value of the composite measures of knowledge of stakeholders, interaction with stakeholders and adaptational behaviour (Plaza-Úbeda et al., 2010).

\subsubsection{Customer demandingness}

Customer demandingness $(\alpha=.96)$ is conceptualised as managers' perception of how their customers are demanding regarding their taste for quality and technological complexity of products (Wang and Netemeyer, 2004). Three items recorded customer demandingness.

\subsubsection{Competitive intensity}

This study defines competitive intensity as a situation where the market environment is characterised by fierce rivalry among competing industry players, leading to high levels of volatility and uncertainty with less growth opportunity within the industry (Auh and Menguc, 2005). Four items taken from Jansen et al. (2006) measured competitive intensity $(\alpha=.87)$.

\subsubsection{Firm-level product innovativeness}

In emerging economies, we know that innovation is focused on incremental changes to practices rather than radical new products (Robson et al. 2012). Accordingly, firm-level product innovativeness $(\alpha=.91)$ is conceptualised as a firm's ability to launch new products incrementally in a timely manner (Wang and Ahmed, 2004). Three items from previous studies (e.g. Covin and Slevin, 1989; Sandvik and Sandvik, 2003; Deshpandé et al., 1993) captured firm-level product innovativeness.

\subsubsection{Control variables}

This study used four control variables (i.e. firm size, firm age, exporting and environmental uncertainty) to account for their impact on the dependent variable. A logarithm of number of employees was used 
as the measure of firm age. Also, firm age was measured as a logarithm of number of years since the firm started operating (Akgün et al., 2012). In addition, this study controlled for exporting because prior research indicates that exporting relates to innovation (e.g. Kleinknecht, 1996). Exporting was a dummy variable $(0=$ local; $1=$ international $)$. Finally, environmental uncertainty was controlled for in this study (Akgün et al., 2012). The environmental uncertainty construct was measured with five items (Jaworski and Kohli, 1993).

\subsection{Measure validation and reliability tests}

This study used LISREL 8.71 and examined all the multi-item constructs in confirmatory factor analysis (CFA) utilising the maximum likelihood method. The traditional chi-square $\left(\chi^{2}\right)$ and other recommended fit heuristics were used to assess the overall fit of the model. Following Cadogan et al. (2006), the scales were analysed in subsets. This study estimated four competing models allowing each

item to load on a single construct (Table 1). First, SI involving the three dimensions (knowledge of shareholders, shareholder interactions and adaptational behaviour) was estimated in measurement Model 1. The second measurement model included competitive intensity, customer demandingness and environmental uncertainty (measurement Model 2). The third model involved firm innovativeness while measurement Model 4 included modelling concurrently all items retained in Model 1 through to Model 3. Appendix 1 contains all the items, t-values and results of measure validation and reliability.

\section{Insert Table 1 about here}

To attenuate potential common method bias issues in the data, this study followed the approaches recommended by Carson (2007), and Lindell and Whitney (2001). First, utilising insights from Carson (2007), this study estimated a combined CFA corresponding measurement model to include all the 
multi-item constructs as well as establishing a common factor to load all the items. This was done to control for any variance and covariance as a result of obtaining data from a single informant. In the process, two competing models were established: Model 1 was a trait-only model that allows each indicator to load on its usual latent factor. Findings from Model 1 show a good fit: $\chi^{2} / \mathrm{df}=1.59$; $\mathrm{p}<.01 ; \mathrm{RMSEA}=.05 ; \mathrm{NNFI}=.96 ; \mathrm{CFI}=.97 ; \mathrm{SRMR}=.06$. Model 2 was an established trait-method model in which a common factor links all the indicators. Results from Model 2 indicate an acceptable fit: $\chi^{2} / \mathrm{df} .=1.93 ; \mathrm{p}<.01 ; \mathrm{RMSEA}=.03 ; \mathrm{NNFI}=.95 ; \mathrm{CFI}=.94 ;$ SRMR $=.05$. When the two models are compared, it can be seen that Model 2 is not materially better than Model 1. Second, this study followed Lindell and Whitney's (2001) approach and tested the correlation between a marker variable (i.e. a variable that is theoretically not related to any construct in the conceptual domain) and the main constructs of the study. This study used "I expect more good things to happen to me than bad", which is a measure of optimism, as a marker variable. Results reveal nonsignificant correlation of 1 to .04 . Overall, it is believed that the common method variable did not influence the analyses.

Subsequently, the reliability and validity were assessed (Appendix 1). This study finds support for convergent validity in the constructs due to the significant factor loadings of the items (Anderson and Garbing, 1988). Moreover, the average variance extracted values surpassed the suggested cut-off value of .50 (Bagozzi and Yi, 2012). This study also finds evidence of discriminant validity because the confidence intervals of the construct correlations did not involve $1.0(p<.05)$ (Anderson and Garbing, 1988). In addition, the AVE values were larger than the squared correlations of the corresponding pairs of constructs (Fornell and Larcker, 1981). This confirms reliability and discriminant validity of the constructs used in the study.

Insert Table 2 about here 


\subsection{Model estimation}

This study used a hierarchical regression method to examine the hypotheses. Hierarchical regression is useful when evaluating configurational and contextual models (Cohen et al., 2003). The use of hierarchical regression demands that all the variables, including the interaction terms, are added in sequence (Wiklund and Shepherd, 2005). To avoid any spurious relationships caused by multicollinearity in the multivariate regression models, all the variables were standardised before the main regressions (Aiken and West, 1991). To attenuate threats of multicollinearity, all the variables involved in the multivariate regression were mean-centred before the interactions were created. To assess whether multicollinearity affects the data, the variance inflation factor (VIF) of each regression model was inspected. The largest VIF obtained in this study is 3.82, which is less than the usual cutoff value of 10 . This suggests that multicollinearity is not a concern in this study. Consequently, the mean-centred values were used in plotting the interactions terms (Dawson and Richter, 2006).

\section{Results}

Descriptive statistics and inter-construct correlations are provided in Table 2. Table 3 presents the results of the moderated regression analyses. Model 1 contains only the control variables. Model 2 adds the main effects variables. Model 3 contains the interaction term for the joint effect of stakeholder interaction and competitive intensity. Model 4 enters the interaction of SI and customer demandingness. In Model 5, a three-way interaction between SI, competitive intensity and customer demandingness was specified. Finally, Model 6 re-estimated the regression for all the five iterations.

\section{Insert Table 3 about here}

Hypothesis 1 stated that SI would be positively related to firm-level product innovativeness. This hypothesis is supported in Model $2(\beta=.17, p<.01)$. Hypothesis 2 argued that the effect of SI on firmlevel product innovativeness would be amplified when competition is intense. Hypothesis 2 is 
supported in Model $3(\beta=.33, p<.01)$. The interaction for hypothesis 2 shows that, when the environment is characterised by intense competition, the effect of SI on firm-level product innovativeness is greater. As Figure 2 shows, the interaction between SI and competitive intensity exerts a positive and significant influence on firm-level product innovativeness. Hypothesis 3 stated that, when the environment is characterised by demanding customers, the innovation benefits a firm obtains from higher SI is greater. Similarly, as Figure 3 shows, the interaction between SI and customer demandingness has a positive and significant influence on firm-level product innovativeness.

\section{Insert Figure 2 about here}

To establish the robustness of the regression models, several additional tests were run. First, a threeway interaction variable was created and entered in Model 5 (stakeholder integration x competitive intensity x customer demandingness). The result of the three-way interaction coefficient is significant $(\beta=.33, p<.01)$. Additional checks revealed that the $\mathrm{R}_{2}$ shows an improvement in model fit between Model 4 and Model 5. As shown in Figure 4, the effect of SI on firm-level product innovativeness is at greater levels of competitive intensity and customer demandingness. Second, going beyond the usually inspected VIFs and inter-construct correlations for assessing threat of multicollinearity, this study followed Echambadi and Hess (2007) and re-estimated all the regression models for the six iterations in Model 6. The results show stability in regression coefficients in terms of direction. This reveals that the data used in the current study are not affected by multicollinearity.

\section{Insert Figure 3 about here}

Third, this study investigated direction of causality by utilising the approach recommended by Landis and Dunlap (2000) for assessing causality in cross-sectional data. To do this, firm-level innovativeness was set as a predictor variable and SI as an outcome variable, and examined the interactive effect of 
innovativeness and the moderating variables (competitive intensity and customer demandingness) on SI. The results revealed non-significant coefficients for reverse interaction terms. Hence, reverse causality seems not to have affected the data (Cao et al., 2009; Landis and Dunlap, 2000).

\section{Insert Figure 4 about here}

\section{Discussion and conclusion}

This study sought to examine the effect of SI on firm-level product innovativeness and the moderating influence of market environment (i.e. competitive intensity and customer demandingness) on this relationship. Using data gathered from 248 manufacturing SMEs in Ghana, we found that a firm's SI capability significantly and positively relates to innovation. Moreover, we found that, under conditions of higher competitor pressure (i.e. competitors undertaking high levels of innovative activities in a firm's target industry), the effect of SI capability on firm product innovativeness is greater. Furthermore, we demonstrated that greater expectations or demand from customers positively and significantly influence the relationship between SI capability and innovation.

Regarding theoretical implications, we contribute to literature on stakeholder integration (Ayuso et al., 2006; Jonas et al., 2018) by showing how SI influences firm innovation in an emerging market. Unlike previous studies that were conducted in developed economies (e.g. Ayuso et al., 2006, 2011), this study shows that in an institutionally challenged environment such as Ghana, the integration of stakeholders is crucial for firm innovation. Thus, we extend stakeholder theory and innovation literature beyond a developed market perspective. By so doing, our study contributes to new lines of research on the challenges in doing business in the resource-constrained setting of emerging economies (Khanna et al., 2005) by shedding light on product innovativeness to understand how SI influences firm innovativeness. This indicates that context plays an important role in innovation and entrepreneurship theory development (Zahra, 2007). Second, this study draws on classical contingency theory (Lawrence 
and Lorsch 1967; Lumpkin and Dess 1996) to examine the conditions under which SI capability is effective in driving innovation. Specifically, we introduced customer demandingness and competitive intensity as moderating factors in the relationship between SI and firm innovation. This approach further extends the stakeholder and innovation literature beyond developed markets. Specifically, this study draws on contextual idiosyncrasies of emerging countries to present a modified model of the moderating role of market environment of the SI-innovation relationship. While some studies have examined the effect of stakeholder management on firm innovation (e.g. Ayuso et al., 2006, 2011; Minoja, 2012), no research has investigated the extent to which market environment may moderate the effect of SI on firm innovation. This implication of this contribution is that the integration of stakeholders into organisational processes is more beneficial when competition and customer demandingness are stronger. This finding offers an interesting extension to the work of Ayuso et al. (2011) and Minoja (2012).

Beyond its theoretical value, our study offers some important contributions. First, our study shows that inter-organisational knowledge development (i.e. the firm and stakeholders) should go handin-hand with intra-organisational knowledge diffusion (i.e. within the organisation) to ensure that stakeholders' concerns feed into new product/service development processes. Given that SI is crucial for innovation, stakeholders' concerns and issues should be integrated into firm-level policies. This is important given that rival firms can subsequently imitate the advantage by demonstrating attentiveness to stakeholders as well as offering superior products. Therefore, it is important for firms to shift to a more proactive and continuous engagement with stakeholders to maintain a competitive edge. Second, our study can guide emerging-market SMEs to improve their innovation performance through the use of SI, when industry competition is intense as well as when customers are highly demanding. Our findings indicate that high levels of competitive intensity and customer demandingness bolster the potency of SI in enhancing innovation. The implication is that firms operating in a highly competitive 
industry environment as well as firms with demanding customers should design strategies to include stakeholders in order to enhance innovation.

\subsection{Limitations and future research directions}

This paper has some limitations which should be taken into consideration when interpreting the findings. First, we utilise a single country’s data. Given that many West African countries are similar in terms of institutional settings, it might be worthwhile for future studies to explore the issue using multiple nations. Second, our analysis is limited to the manufacturing sector which is shaped by industry-specific conditions, including regulations and industrial standards. There is a need for crossindustrial analysis to help assess whether the findings can be extended to other settings. Third, the use of cross-sectional data limits our ability to make causal claims on the findings. Future research may wish to use longitudinal data to investigate the linkages specified in this study. Given that we did not consider adding $R \& D$ investments or $R \& D$ intensity of the firm as control variables, future studies could incorporate these. In addition, we used a uni-dimensional stakeholder construct to examine its effect on innovation. As such, we could not examine how the dimensions of the SI construct (i.e. knowledge, interaction and adaptation) perform separately on firm innovation. We recommend that future studies should take steps to examine how these dimensions may separately influence firm innovation. Future studies could also explore the expectation of customers in Ghana. Finally, future research could explore the potential link between customers' demands and sustainable development.

\section{References}

Adomako, S., Opoku, R. A., \& Frimpong, K. (2017). The Moderating Influence of Competitive Intensity on the Relationship between CEOs' Regulatory Foci and SME Internationalization. Journal of International Management, 23(3), 268-278.

Afuah, A. (2009). Strategic Innovation: New Game Business Models for Competitive Advantage. Routledge: New York.

Aiken, L. and West, S. (1991) Multiple Regression: Testing and Interpreting Interactions. Newbury Park, Sage. Akgün, A.E., Keskin, H., and Byrne, J. (2012) Antecedents and contingent effects of organizational adaptive capability on firm product innovativeness. Journal of Product Innovation Management, 29, 171-189. 
Alsos, A. G., Hytti, U., \& Ljunggren, E. (2011). Stakeholder theory approach to technology incubators. International Journal of Entrepreneurial Behavior \& Research, 17(6), 607-625.

Amankwah-Amoah, J., Debrah, Y. A., \& Nuertey, D. (2018). Institutional legitimacy, cross-border trade and institutional voids: Insights from the cocoa industry in Ghana. Journal of Rural Studies, 58, 136-145.

Anderson, J.C. and Gerbing, D.W. (1988) Structural equation modeling in practice: A review and recommended two-step approach. Psychological Bulletin, 103, 411-423

Armstrong, J.S. and Overton, T.S. (1977) Estimating nonresponse bias in mail surveys. Journal of Marketing Research, 14, 396-402.

Auh, S. and Menguc, B. (2005) Balancing exploration and exploitation: the moderating role of competitive intensity. Journal of Business Research, 58, 1652-1661.

Ayuso, S., Rodriguez, M.A., and Ricart, J.E. (2006) Using stakeholder dialogue as a source for new ideas: a dynamic capability underlying sustainable innovation. Corporate Governance, 6, 475-490.

Ayuso, S., Rodríguez, M.A., García- Castro, R., and Ariño, M.A. (2011) Does stakeholder engagement promote sustainable innovation orientation? Industrial Management \& Data Systems, 111, 1399-1417.

Ayyagari, M., Demirgüç-Kunt, A., \& Maksimovic, V. (2011). Firm innovation in emerging markets: the role of finance, governance, and competition. Journal of Financial and Quantitative Analysis, 46(6), 15451580.

Bagozzi, R.P. and Yi, Y. (2012) On the evaluation of structural equation models. Journal of the Academy of Marketing Science, 14, 33-46.

Banin, A.Y., Boso, N., Hultman, M., Souchon, A.L., Hughes, P., and Nemkova, E. (2016) Salesperson improvisation: Antecedents, performance outcomes, and boundary conditions. Industrial Marketing Management, 59, 120-130.

Bonney, F. L., \& Williams, B. C. (2009). From products to solutions: The role of salesperson opportunity recognition. European Journal of Marketing, 43, 1032-1052.

Cadogan, J.W., Cui, C.C., Morgan, R.E., and Story, V.M. (2006). Factors facilitating and impeding the development of export market-oriented behavior: A study of Hong Kong manufacturing exporters. Industrial Marketing Management, 35, 634-647.

Cao, Q., Gedajlovic, E., and Zhang, H. (2009) Unpacking organizational ambidexterity: Dimensions, contingencies, and synergistic effects. Organization Science, 20, 781-796.

Carson, S.J. (2007) When to give up control of outsourced new product development. Journal of Marketing, 71, 49-66.

Cavusgil, S. T., Ghauri, P. N., \& Akcal, A. A. (2012). Doing business in emerging markets. London: Sage.

Cavusgil, S.T., Knight, G.A. and Riesenberger, J.R. (2012). International Business: Strategy, Management, and the New Realities, 2nd ed., Pearson Prentice Hall, Upper Saddle River, NJ.

Chesbrough, H.W. (2006). Open innovation: The new imperative for creating and profiting from technology. Harvard Business Press.

Cimoli, M., Dosi G., and Stiglitz, J.E. (2009). Industrial Policy and Development: The Political Economy of Capabilities Accumulation. New York: Oxford University Press.

Cohen, J., Cohen, P., West, S.G., and Aiken, L.S. (2003). Applied Multiple Regression/Correlation Analysis for the Behavioral Sciences, 3rd Ed. Lawrence Erlbaum, New Jersey.

Covin, J. G., \& Slevin, D. P. (1991). A conceptual model of entrepreneurship as firm behavior. Entrepreneurship theory and practice, 16(1), 7-26.

Covin, J.G. and Slevin, D.P. (1989) Strategic management of small firms in hostile and benign environments. Strategic Management Journal, 10, 75-87.

Cui, A. S., Griffith, D. A., \& Cavusgil, S. T. (2005). The influence of competitive intensity and market dynamism on knowledge management capabilities of multinational corporation subsidiaries. Journal of International Marketing, 13(3), 32-53.

Dahl, D.W., Fuchs, C., and Schreier, M. (2014) Why and when consumers prefer products of user-driven firms: A social identification account. Management Science, 61, 1978-1988.

Delmar, F., Karl Wennberg \& K. Hellerstedt (2011) Endogenous growth through knowledge spillovers in entrepreneurship: an empirical test. Strategic Entrepreneurship Journal, 5, 199-226.

Dawson, J.F. and Richter, A.W. (2006) Probing three-way interactions in moderated multiple regression: Development and application of a slope difference test. Journal of Applied Psychology, 91, 917-926. 
Desai, V.M. (2018) Collaborative stakeholder engagement: an integration between theories of organizational legitimacy and learning. Academy of Management Journal, 61, 220-244.

Deshpandé, R., Farley, J.U., and Webster Jr, F.E. (1993). Corporate culture, customer orientation, and innovativeness in Japanese firms: a quadrad analysis. Journal of Marketing, 57, 23-37.

Donaldson, T. and Preston, L.E. (1995) The stakeholder theory of the corporation: Concepts, evidence, and implications. Academy of Management Review, 20, 65-91.

Driessen, P.H., Kok, R.A., and Hillebrand, B. (2013) Mechanisms for stakeholder integration: Bringing virtual stakeholder dialogue into organizations. Journal of Business Research, 66, 1465-1472.

Echambadi, R. and Hess, J.D. (2007) Mean-centering does not alleviate collinearity problems in moderated multiple regression models. Marketing Science, 26, 438-445.

Eesley, C. and Lenox, M.J. (2006) Firm responses to secondary stakeholder action. Strategic Management Journal, 27, 765-781.

Fornell, C. and Larcker, D.F. (1981) Structural equation models with unobservable variables and measurement error: Algebra and statistics. Journal of Marketing Research, 18, 382-388.

Freeman, R.E. (1984) Strategic management: A stakeholder approach. Boston, MA: Pitman.

Galunic, D.C. and Rodan, S. (1998) Resource recombinations in the firm: Knowledge structures and the potential for Schumpeterian innovation. Strategic Management Journal, 19, 1193-1201.

Garcia, R. and Calantone, R. (2002). A critical look at technological innovation typology and innovativeness terminology: a literature review. Journal of Product Innovation Management, 19, 110-132.

Germann, F., Lilien, G. L., \& Rangaswamy, A. (2013). Performance implications of deploying marketing

analytics. International Journal of Research in Marketing, 30(2), 114-128.

Goodman, J., Korsunova, A., and Halme, M. (2017) Our collaborative future: activities and roles of stakeholders in sustainability-oriented innovation. Business Strategy and the Environment, 26, 731-753.

Grant, R.M. (1996). Toward a knowledge-based theory of the firm. Strategic Management Journal, 17, 109-22

Hart, S.L. (1995) A natural resource-based view of the firm. Academy of Management Review 20, 986-1014.

Hart, S.L. and Sharma, S. (2004) Engaging fringe stakeholders for competitive imagination. Academy of Management Executive, 18, 7-18.

Henard, D.H. and Szymanski, D.M. (2001) Why some new products are more successful than others. Journal of Marketing Research, 38, 362-375.

Holmes, S. and Smart, P. (2009) Exploring open innovation practice in firm- nonprofit engagements: a corporate social responsibility perspective. R\&D Management, 39, 394-409.

Hurley, R.F. and Hult, G.T.M. (1998) Innovation, market orientation, and organizational learning: An integration and empirical examination. Journal of Marketing, 62, 42-54.

Jamali, D., \& Karam, C. (2018). Corporate social responsibility in developing countries as an emerging field of study. International Journal of Management Reviews, 20, 32-61.

Jansen, J.J.P., Van Den Bosch, F.A.J., and Volberda, H.W. (2006) Exploratory innovation, exploitative innovation, and performance: Effects of organizational antecedents and environmental moderators. Management Science, 52, 661-1674.

Jaworski, B.J. and Kohli, A.K. (1993) Market orientation: antecedents and consequences. Journal of Marketing, 53-70.

Jonas, J.M. and Roth, A. (2017). Stakeholder integration in service innovation-an exploratory case study in the healthcare industry. International Journal of Technology Management, 73, 91-113.

Jonas, J.M., Boha, J., Sörhammar, D., and Moeslein, K.M. (2018) Stakeholder engagement in intra-and interorganizational innovation: Exploring antecedents of engagement in service ecosystems. Journal of Service Management.

Khanna, T., Palepu, K.G., and Sinha, J. (2005) Strategies that fit emerging markets. Harvard business review, 83, 4-19.

Kleinknecht, A. (1996). Determinants of innovation: the message from new indicators. MacMillan, London.

Landis, R.S. and Dunlap, W.P. (2000). Moderated multiple regression tests are criterion specific. Organizational Research Methods, 3, 254-266.

Lawrence, P. R. and Lorsch, J. W. (1967). Differentiation and integration in complex organizations. Administrative Science Quarterly, 1-47. 
Lindell, M.K. and Whitney, D.J. (2001) Accounting for common method variance in cross-sectional research designs. Journal of Applied Psychology, 86, 114-121.

Luo, L., and Tung, R. L.. (2007). International expansion of emerging market enterprises: A springboard perspective. Journal of International Business Studies 38: 481-98.

Luo, Y., J. Sun, and Wang, L. S. (2011). Emerging economy copycats: Capability, environment, and strategy. Academy of Management Perspectives 25: 37-56.

Minoja, M. (2012). Stakeholder management theory, firm strategy, and ambidexterity. Journal of Business Ethics, 109(1), 67-82.

Morgan, N.A., Kaleka, A., and Katsikeas, C.S. (2004) Antecedents of export venture performance: A theoretical model and empirical assessment. Journal of Marketing, 68, 90-108.

Obeng, B. A., Robson, P., \& Haugh, H. (2014). Strategic entrepreneurship and small firm growth in Ghana. International Small Business Journal, 32(5), 501-524.

Ommen, N.O., Blut, M., Backhaus, C., and Woisetschläger, D.M. (2016). Toward a better understanding of stakeholder participation in the service innovation process: More than one path to success. Journal of Business Research, 69, 2409-2416.

Özçelik, E. and Taymaz, E. (2004). Does innovativeness matter for international competitiveness in developing countries? The case of Turkish manufacturing industries. Research Policy, 33, 409-424.

Peters, T.J. and Waterman, R.H. (1982) In search of excellence: Lessons from America's best run companies. New York: Harper \& Row.

Phillips, W., Alexander, E.A., and Lee, H. (2017) Going it alone won't work! The relational imperative for social innovation in social enterprises. Journal of Business Ethics, 1-17.

Plaza-Úbeda, J.A., de Burgos-Jiménez, J., and Carmona-Moreno, E. (2010) Measuring stakeholder integration: knowledge, interaction and adaptational behavior dimensions. Journal of Business Ethics, 93, 419-442.

Robson, P.J.A., Haugh, H.M., and Obeng, B.A. (2009) Entrepreneurship and innovation in Ghana: enterprising Africa. Small Business Economics, 32, 331-350.

Romanelli, E., \& Khessina, O. M. (2005). Regional industrial identity: Cluster configurations and economic development. Organization Science, 16(4), 344-358.

Sandvik, I.L., and Sandvik, K. (2003). The impact of market orientation on product innovativeness and business performance. International Journal of Research in Marketing, 20, 355-376.

Sawhney, M., Wolcott, R.C., and Arroniz, I. (2006). The 12 different ways for companies to innovate. MIT Sloan Management Review, 47, 75.

Senge, P. and Carstedt, G. (2001) Innovating our way to the next industrial revolution. MIT Sloan Management Review, 42, 24-38.

Sharma, S. and Vredenburg, H. (1998) Proactive environmental strategy and the development of competitively valuable organizational capabilities. Strategic Management Journal, 19, 729-753.

Story, V.M., Boso, N., and Cadogan, J.W. (2015) The form of relationship between firm- level product innovativeness and new product performance in developed and emerging markets. Journal of Product Innovation Management, 32, 45-64.

Tajeddini, K., Trueman, M., and Larsen, G. (2006) Examining the effect of market orientation on innovativeness. Journal of Marketing Management, 22, 529-551.

Talke, K. and Hultink, E.J. (2010) Managing diffusion barriers when launching new products. Journal of Product Innovation Management, 27, 537-553.

Vargo, S.L. and Lusch, R.F. (2004) Evolving to a new dominant logic for marketing. Journal of Marketing, 68 , $1-17$.

Viglia, G., Pera, R., and Bigné, E. (2018) The determinants of stakeholder engagement in digital platforms. Journal of Business Research. 89, 404-410.

Wang, C.L. and Ahmed, P.K. (2004) The development and validation of the organisational innovativeness construct using confirmatory factor analysis. European Journal of Innovation Management, 7, 303-313.

Wang, G. and Netemeyer, R.G. (2004) Salesperson creative performance: conceptualization, measurement, and nomological validity. Journal of Business Research, 57, 805-812. 
Watson, R., Wilson, H.N., Smart, P., and Macdonald, E.K. (2018). Harnessing difference: A capability-based framework for stakeholder engagement in environmental innovation. Journal of Product Innovation Management, 35, 254-279.

Wiklund, J. and Shepherd, D. (2005) Entrepreneurial orientation and small business performance: a configurational approach. Journal of Business Venturing, 20, 71-91.

World Bank (2011) The Little Data Book on Africa 2011. DC: Washington.

World Bank (2017) Doing Business Report. Available at http//www.doingbusiness.org, Accessed on 23/03/2017.

Zahra, S.A. (1993). Environment, corporate entrepreneurship, and financial performance: a taxonomic approach. Journal Business Venturing, 8, 319-340.

Zahra, S.A. (2007) Contextualizing theory building in entrepreneurship research. Journal of Business Venturing, 22, 443-452. 


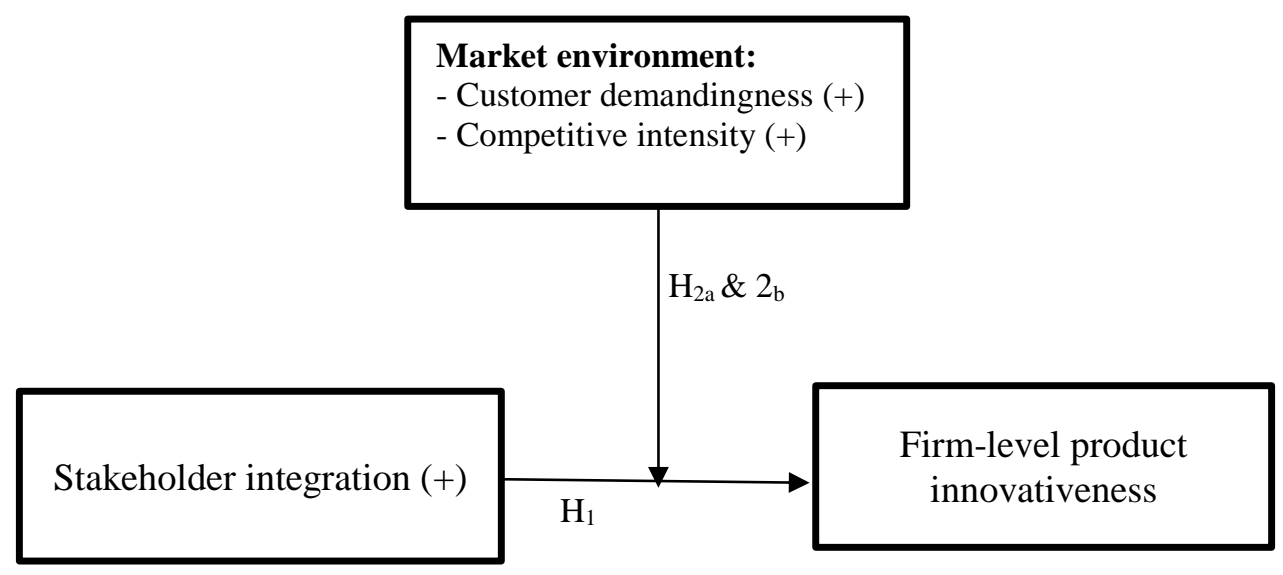

Fig. 1: Conceptual model and hypotheses

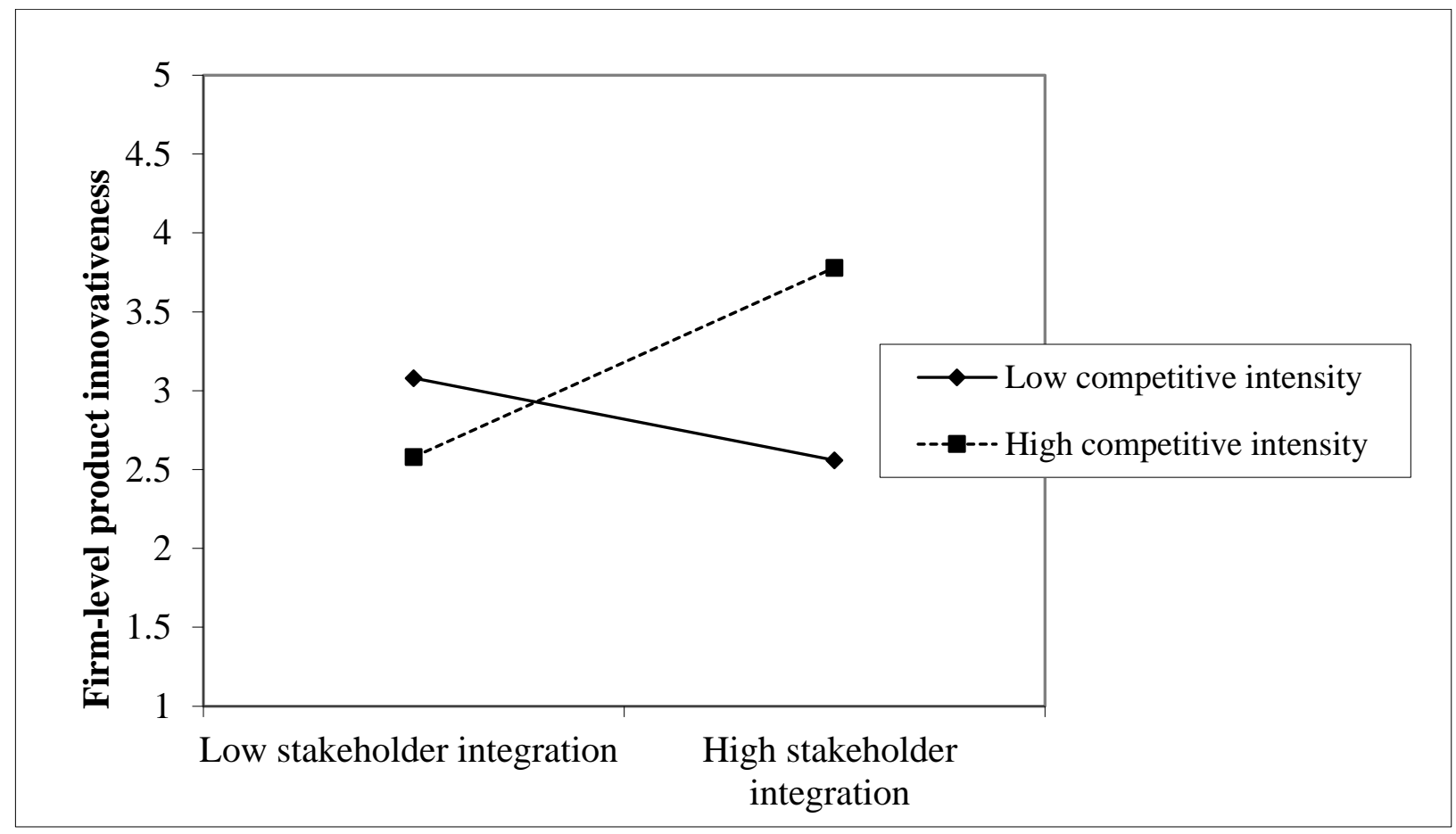

Fig. 2: Interaction effect of stakeholder integration with competitive intensity on firm-level product innovativeness 


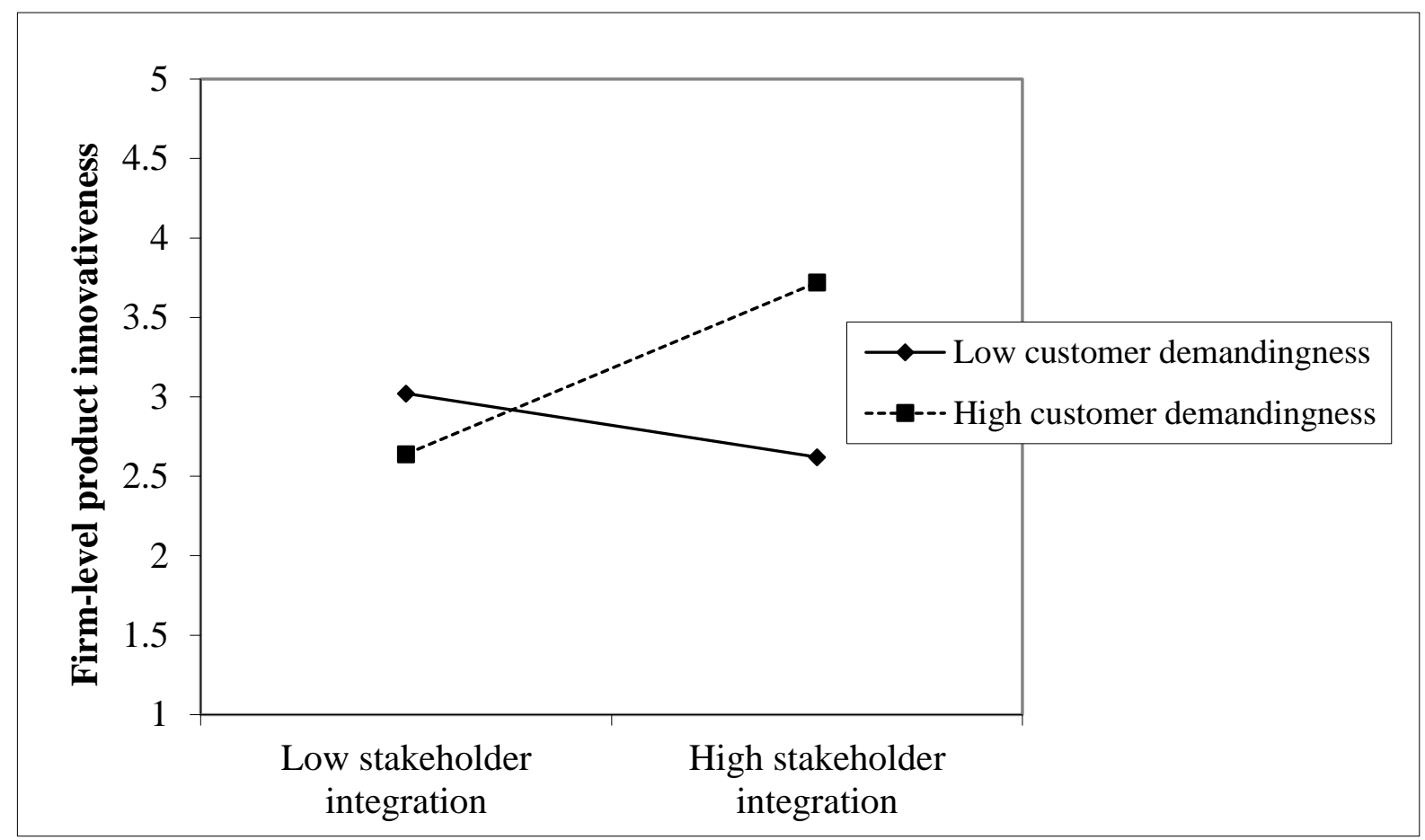

Fig. 3: Interaction effect of stakeholder integration with customer demandingness on firm-level product innovativeness 


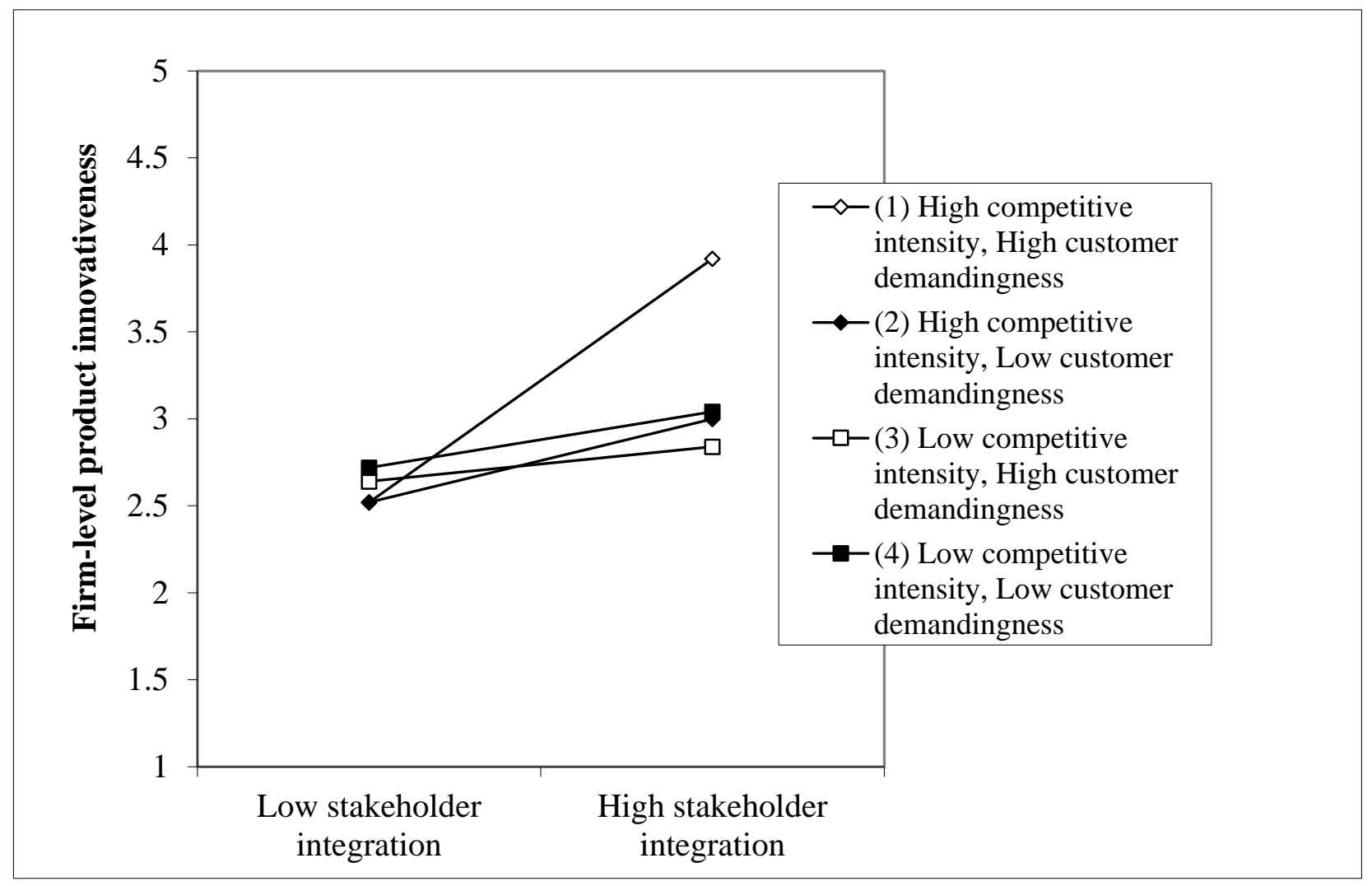

Fig. 4: Interaction effect of stakeholder integration, competitive intensity and customer demandingness on firm-level product innovativeness 


\section{Table 1: Fit indices for the measurement models}

\begin{tabular}{lcccccccc}
\hline CFA Models & $\chi^{2}$ & $\mathrm{df}$ & $\chi^{2} / \mathrm{df}$ & $\mathrm{p}$-value & RMSEA & SRMR & NNFI & CFI \\
\hline Measurement model 1 & 385.22 & 221 & 1.74 & .14 & .05 & .03 & .91 & .95 \\
Measurement model 2 & 98.33 & 67 & 1.46 & .03 & .03 & .04 & .95 & .96 \\
Measurement model 3 & 88.22 & 72 & 1.22 & .00 & .05 & .05 & .97 & .98 \\
Full measurement model 4 & 2608.90 & 1998 & 1.30 & .00 & .05 & .05 & .95 & .97 \\
\hline
\end{tabular}

Note: Measurement (set 1) = Shareholder integration (knowledge of shareholders, shareholder interactions and adaptational behaviour); measurement (set 2) = competitive intensity, customer demandingness and environmental uncertainty; measurement (set 3) = firm innovativeness; measurement (set 4): all items retained in sets 1 through to 3 were modelled concurrently.

\section{Table 2: Descriptive statistics and inter-construct correlations}

\begin{tabular}{|c|c|c|c|c|c|c|c|c|c|c|c|}
\hline & Variables & Mean & S.D & 1 & 2 & 3 & 4 & 5 & 6 & 7 & 8 \\
\hline 1. & $\begin{array}{l}\text { Firm-size (full- } \\
\text { time employees }\end{array}$ & 61.79 & 67.76 & & & & & & & & \\
\hline 2. & Firm age & 7.89 & 5.54 & $.37 * *$ & & & & & & & \\
\hline 3. & Exporting & 1.71 & .45 & .06 & $.18 * *$ & & & & & & \\
\hline 4. & $\begin{array}{l}\text { Environmental } \\
\text { uncertainty }\end{array}$ & 4.10 & .85 & $.20 * *$ & $.13 *$ & .11 & $(.74)$ & & & & \\
\hline 5. & $\begin{array}{l}\text { Stakeholder } \\
\text { integration }\end{array}$ & 4.75 & .53 & -.06 & .09 & $.22 * *$ & $.28^{* *}$ & (.79) & & & \\
\hline 6. & $\begin{array}{l}\text { Competitive } \\
\text { intensity }\end{array}$ & 5.02 & .72 & .02 & $.21 * *$ & $.18 * *$ & .05 & $.39 * *$ & (.83) & & \\
\hline 7. & $\begin{array}{l}\text { Customer } \\
\text { demandingness }\end{array}$ & 5.31 & .75 & .02 & $.14^{*}$ & .00 & $.15^{*}$ & $.27 * *$ & $.38 * *$ & (.80) & \\
\hline 8. & $\begin{array}{l}\text { Firm product } \\
\text { innovativeness }\end{array}$ & 4.95 & .69 & -.04 & -.02 & $.25^{* *}$ & $.29 * *$ & $.43^{* *}$ & $.36^{* *}$ & $.28 * *$ & (.88) \\
\hline
\end{tabular}

${ }^{*} \mathrm{p}<0.05 ;{ }^{* *} \mathrm{p}<.01$ (2-tailed test); S.D. = Standard deviation. ${ }^{\mathrm{a}}$ Natural logarithm. Square root of average variance extracted in diagonal 
Table 3: Results of standardised moderated hierarchical regression analyses

\begin{tabular}{|c|c|c|c|c|c|c|}
\hline \multirow{2}{*}{ Independent Variables } & \multicolumn{6}{|c|}{ Dependent variable: Firm product innovativeness $(\mathrm{N}=248)$} \\
\hline & Model 1 & Model 2 & Model 3 & Model 4 & Model 5 & Model 6 \\
\hline \multicolumn{7}{|l|}{ Control variables } \\
\hline Firm size (full-time employees) & -.04 & -.02 & -.03 & -.03 & -.04 & -.04 \\
\hline Firm age (years) & -0.2 & -.05 & $-.08 *$ & $-.09 *$ & $-.10^{*}$ & -.03 \\
\hline Exporting & $.15^{* * *}$ & $.16^{* * *}$ & $.19 * * *$ & $.22 * * *$ & $.21 * * *$ & $.16^{* * *}$ \\
\hline Environmental uncertainty & $.21 * * *$ & $.18 * * *$ & $.15^{* * *}$ & $.15^{* * *}$ & $.19 * * *$ & $.20 * * *$ \\
\hline \multicolumn{7}{|l|}{ Direct effects } \\
\hline $\mathrm{H}_{1}$ : Stakeholder integration (SI) & & $.17 * * *$ & $.23 * * *$ & $.24 * * *$ & $.25 * * *$ & $.19 * * *$ \\
\hline Competitive intensity (CI) & & $.18 * * *$ & $.19 * * *$ & $.20 * * *$ & $.22 * * *$ & $.16^{* * *}$ \\
\hline Customer demandingness (CD) & & $.20 * * *$ & $.17 * * *$ & $.18 * * *$ & $.19 * * *$ & $.20 * * *$ \\
\hline \multicolumn{7}{|l|}{ Moderating effects } \\
\hline $\mathrm{H}_{2 \mathrm{a}}: \mathrm{SI} x \mathrm{CI}$ & & & $.33 * * *$ & $.32 * * *$ & $.34 * * *$ & $.34 * * *$ \\
\hline $\mathrm{H}_{2 \mathrm{~b}}: \mathrm{SI} \times \mathrm{CD}$ & & & & $.41 * * *$ & $.43 * * *$ & $.41 * * *$ \\
\hline \multicolumn{7}{|l|}{ Three-way interaction effect } \\
\hline SI x CI x CD & & & & & $.63 * * *$ & $.64 * * *$ \\
\hline \multicolumn{7}{|l|}{ Model fit statistics } \\
\hline F-value & $5.86^{* * *}$ & $14.04 * * *$ & $15.06 * * *$ & $17.89 * * *$ & $18.33 * * *$ & $19.92 * * *$ \\
\hline $\mathrm{R}^{2}$ & .08 & .22 & .27 & .31 & .39 & .42 \\
\hline$\Delta \mathrm{R}^{2}$ & - & .14 & .05 & .04 & .08 & .03 \\
\hline Mean VIF & 1.12 & 1.15 & 1.12 & 2.64 & 3.82 & 2.22 \\
\hline
\end{tabular}

$* * * p<0.01 ; * * p<0.05 ; * p<0.10$. Standardized coefficients are shown 